\title{
Sector holdings in mutual fund performance: an analysis
}

\author{
Ghose, Soheli. M.Phil, B.Ed. \\ Assistant Professor, Department of Commerce \\ J.D.Birla Institute (Jadavpur University), India.
}

\begin{abstract}
Mutual Funds in India are fast gaining ground as the latest investment option for both Institutional and retail Investors. In the last few years, we witnessed a global economic meltdown, which affected the worldwide financial markets in varying degrees. The so called Recovery Phase of the economic recession is being slowed down due to the deepening debt crisis in the developed countries, political corruption which has gripped our nation and inflation to name a few. In this context I have studied the effect and role of Sector Holdings on the Performance of Mutual Funds in the fluctuating financial markets analysing 1 public sector (UTI Opportunities) and 2 private sector mutual fund schemes ( HDFC Equity, Tata Equity PE) between January 2010 and September 2011 covering the turbulent period of this economic crisis.
\end{abstract}

Key words: Company Holdings, Equity Diversified Schemes, Open Ended Mutual Fund Schemes, Sector Holdings.

\section{Introduction}

According to the Association of Indian Mutual Fund Industry, "A Mutual Fund is a trust that pools the savings of a number of investors who share a common financial goal. The money thus collected is then invested in capital market instruments such as shares, debentures and other securities. The income earned through these investments and the capital appreciation realized is shared by the unit holders in the proportion to the number of units owned by them. Thus a mutual fund is the most suitable investment for the common man as it offers an opportunity to invest in a diversified professionally managed basket of securities at a relatively low cost." Mutual funds act as a financial intermediary in activities of fund mobilization and investment [1]. The essence of a Mutual Fund is the diversified portfolio of investment, which diversifies the risk by spreading out the investor's money across available or different types of investments. Thus, Indian Mutual Funds are playing a very crucial developmental role in allocating resources in the emerging market economy [2]. Of all investing institutions, Mutual Funds have grown at the fastest rate due to their operational flexibility and because they provide better returns to the investors and serve as a sophisticated market-clearing agent [3]. This paper is divided into the following sections: Section 2: about the Rationale of Mutual Funds, Section 3: about History of Mutual Funds in India, Section 4: about Literature Survey relevant to this study, Section5: about Objective and Methodology of the Study, Section 6: about the Observations and Inferences, Section 7: contains the concluding remarks and the relevance of the study and finally Section 8: depicts the relevant charts and tables used in the study.

\section{Rationale of Mutual Fund}

Mutual funds diversify in a predetermined category of investments. Thus without spending considerable time and money small investors can enjoy the facility of diversification reducing and spreading the risk factor of investors [4]. Through mutual fund, investors can purchase stocks or bonds with much lower trading costs. Mutual funds provide investors with various schemes with different investment objectives. Investors can switch their holdings from a debt scheme to an equity scheme and vice-versa. Option of systematic investment and withdrawal is offered to the investors in most open-end schemes. The minimum investment in a Mutual Fund is relatively smaller than that of shares. Mutual Fund industry is part of a wellregulated investment environment where the interests of the investors are protected by the regulator. All funds are registered with SEBI. Mutual Funds provide the benefit of skilled portfolio management by professional managers, to small investors who otherwise cannot afford such expertise or knowledge [5]. Units of a mutual fund offer sufficient liquidity. The stock market fluctuations seem to have less impact over Mutual funds. Mutual Funds play a dynamic role in mobilizing savings by issuing units and channelling funds in the capital market into productive investment. The growth of Mutual Funds has helped accelerate the development of the capital market, by channeling a growing part of savings of the household sector into equity invetments and also by increasing awareness about capital markets among many investors [6]. 


\section{History of Mutual Fund Industry in India}

The formation of Unit Trust of India marked the evolution of the Indian mutual fund industry in the year 1963 with the primary objective of attracting the small investors. The history of mutual fund industry in India can be divided into following phases:

Phase 1: Establishment and Growth of UTI - 1964-87: UTI was established by an act of Parliament by the Reserve Bank of India and operated under RBI until the two were delinked in 1978 and the entire control was transferred to IDBI. UTI launched Unit Scheme in 1964. It launched ULIP in 1971. By the end of 1987, UTI's AUM was Rs 6700 crores.

Phase II. Entry of Public Sector Funds - 1987-1993: In November 1987, SBI Mutual Fund became the first non-UTI mutual fund in India. It was followed by Canbank Mutual Fund (1987), LIC Mutual Fund (1989), Indian Bank Mutual Fund (1989), Bank of India Mutual Fund (1990), GIC Mutual Fund (1990) and PNB Mutual Fund (1989), Bank of Baroda Mutual Fund (1992). By 1993, the AUM of the industry increased to Rs. 47,004 crores. However, UTI remained to be the leader with about $80 \%$ market share.

Phase III. Emergence of Private Sector Funds - 1993-96: By 1994-95, about 11 private sector funds had launched their schemes. In 1993, the first Mutual Fund Regulations came into being, under which all mutual funds, except UTI were to be registered and governed. The erstwhile Kothari Pioneer (now merged with Franklin Templeton) was the first private sector mutual fund registered in July 1993. Many foreign mutual funds set up funds in India and the industry witnessed several mergers and acquisitions. Mutual Funds from Domestic and Foreign Private Sectors had gained ground.

Phase IV. SEBI Regulation - 1996-2004: The mutual fund industry witnessed growth and stricter regulation from the SEBI after 1996 as uniform standards were set for all mutual funds in India. Various Investor Awareness Programmes were launched by SEBI and AMFI, with an objective to educate investors about the mutual fund industry. In February 2003, the UTI Act was repealed and UTI was stripped of its Special legal status bringing all mutual fund players on the same level. UTI was reorganized into two parts (The Specified Undertaking and The UTI Mutual Fund). By the end of September 2004, there were 29 funds, with AUM of Rs. 153108 crores under 421 schemes. However, UTI Mutual Fund was still the largest player in the industry.

Phase V. Growth and Consolidation - 2004 Onwards: The industry has also witnessed several mergers and acquisitions recently (Alliance Mutual Fund by Birla Sun Life, Sun F\&C Mutual Fund and PNB Mutual Fund by Principal Mutual Fund). More international mutual fund players entered India like Fidelity, Franklin Templeton Mutual Fund etc. This is a continuing phase of growth of the industry through consolidation and entry of new international and private sector players. The growth and success of Mutual Fund industry depends upon sound financial management of policies and investment practices. It pursues to bring about value addition to the corpus of Mutual Funds [7]. Fig. 1.

\subsection{The structure of Mutual Funds in India is as follows:}

Sponsors: It's the agency, which of its own or in collaboration with other body corporates comply the formalities of establishing a mutual fund [8].

Trust: A company is appointed as a Trustee to manage Mutual Fund. It's their responsibility to supervise collection of any income due to be paid to the scheme.

Asset Management Company (AMC): The Trustees appoint the AMC, which is established as a legal entity, to manage the investor's money for a fee. The AMC floats new schemes and manages these schemes by buying and selling securities.

Custodian: The Mutual Fund appoints a custodian to hold the funds securities in safekeeping, settle securities transactions for the fund, collect interest and dividend paid on securities and record information on stock splits and other corporate action [9].

Transfer Agents: Registrar and Transfer Agents (RTAs) maintain the investor's (unit holder's) records, reducing the burden on the AMCs. Fig. 2.

Regulatory accountability is of prime importance to the regulated and the investor [10]. More importantly, the goal of regulatory agency is not just to regulate but also to inculcate the culture of self-regulation supported by less external regulation yielding better results [11]. 


\section{Literature Survey}

Research work on Mutual Funds began in 1960s in the U.S.A. and European region. William F. Sharpe [12] was one of the first to introduce a measure for the performance of Mutual Funds, the Sharpe Ratio, (1): $\mathbf{R}(\mathbf{x})=\left(\mathbf{R x}-\mathbf{R}_{\mathbf{f}}\right) / \boldsymbol{\sigma}_{\mathbf{x}}$ $\mathrm{x}$ is some investment; $\mathrm{R}_{\mathrm{x}}$ is the average annual rate of return of $\mathrm{x} ; \mathrm{R}_{\mathrm{f}}$ is the best available rate of return of a "risk-free" security (i.e. cash); $\sigma_{\mathrm{x}}$ is the standard deviation of Rx.

Jack Treynor [13] developed the Treynor Ratio that measures returns earned in excess of that which could have been earned on a risk less investment per each unit of market risk. The ratio is, (2): $\left(\mathbf{r}_{\mathbf{p}}-\mathbf{r}_{\mathbf{f}}\right) / \boldsymbol{\beta}_{\mathbf{p}}$

$\mathbf{r}_{\mathbf{p}}=$ Average return of the portfolio; $\mathbf{r f}=$ Average return of the risk-free proxy; $\boldsymbol{\beta}_{\mathbf{p}}=$ Beta of the portfolio. In their study Guha Deb and Banerjee (2009) [14] used Value at Risk approach (VaR) as a single risk measure summarizing all sources of downward risk. They attempted to highlight the importance of VaR as a measure of 'downside risk' for Indian equity Mutual Funds. Roy and Deb (2003) [15] used the Treynor-Mazuy model and Henriksson-Merton model to measure the Conditional Performance of Indian Mutual Funds. Ferson and Schadt (1996) [16] advocated a technique called conditional performance evaluation measuring the performance with both unconditional and conditional form of - CAPM, Treynor-Mazuy model and Henriksson-Merton model. Recent studies have empirically tested the persistence in fund performance, Volkman and Wohar (1994) [17], but didn't thoroughly investigate other systematic factors affecting future fund performance.

\section{Objective and Methodology}

I have analysed 1 public sector and 2 private sector mutual fund schemes which are $\underline{\text { HDFC Equity }}$ (27), Tata Equity PE (36), UTI Opportunities (47) between January 2010 and September 2011 covering the turbulent period of this economic crisis. It seems that Mutual Fund Industry is a shock absorber to market fluctuations and if it fails to do so, it cannot be differentiated from other types of investments. In these trying times all sectors are getting affected adversely, the performance analysis of Mutual Funds is very pertinent in that context. The study is based on secondary data collected from a sample of top 50 Equity Diversified funds based on rankings provided by Valueresearchonline (A popular and authentic mutual fund research organization) as on $1^{\text {st }}$ January 2010. The second stage sample schemes were taken from these and were analysed for performance and fluctuations, changes in their sector holdings to establish a relation between sector holdings and fund performance during business cycle fluctuations and Correlate various factors with return generated.

\subsection{HDFC EQUITY:}

\section{Observations and Inferences}

In January 2010, it garnered very high return (9.06) which had dropped badly in March 2010 (2.28) but again picked up very well in September 2010 (17.12). However the downfall began in December 2010 onwards when the return was 0.62 and continued plummeting further in March 2011 (-5.1), June 2011 (-0.73) and September 2011 (-12.73) (Graph 1). This negative turn can be explained by the following:

a) The economy as a whole had taken a downward turn from the beginning of 2011 and we later witnessed difficult times both politically and socially which adversely affected the Indian Financial Markets including the Mutual Fund Industry.

b) The major sector holdings were Financial, Energy, Healthcare, FMCG, and Services. The stockholdings in Energy Sector increased from 11.26 to 17.1. The energy (especially crude oil) crisis deepened from early 2011 with oil prices skyrocketing. This may have affected the returns generated towards the later quarters of 2011. The stockholdings in the Healthcare and Financial sector fell from 9.56 and 26.33 in January 2010 to 3.35 and 22.48 in September 2011 respectively. However, with the Sectors performing well overall this reduction in percentage stockholdings may have further affected the performance of the Fund. The holdings in the Communications sector had also increased considerably from 0 to 4.1 This, along with the severe crisis the Telecommunication Industry is going through may have further reduced the reruns. Though there has been a steady rise in the Technology sector, FMCG sector has seen a sharp decrease and as these sectors are performing well overall, the increase in percentage stock holdings in one and decrease in another may have counteracted leading further to the adverse effect of the other sector holdings. Thus, it did not help the returns much (Graph 2 , Table 1).

c) The major changes in the company holdings were Bharti Airtel (0 to 4.1), Oil India (0 to 2.13), Coal India (0 to 2.4) and ONGC (5.95 to 0$)$, which showed in the returns generated (Graph 3, Table 2).

6.2

TATA EQUITY PE:

In January 2010, it garnered very high return (9.64) which had dropped badly in March 2010 (0.67) but again picked up very well in September 2010 (10.41). However the downfall began in December 2010 onwards 
when the return was 0.63 and continued plummeting further in March 2011 (-6.49), June 2011 (-1.71) and September 2011 (-10.26) (Graph 4). This negative turn can be explained as:

a) Same as 1 .

b) The major sector holdings were Financial, Energy, Metals, FMCG, Technology and Services. The stockholdings in Energy Sector jumped from 8.82 to 21.38 . The energy (especially crude oil) crisis deepened from early 2011 with oil prices skyrocketing. This may have affected the returns generated towards the later quarters of 2011. The stockholdings in the Services and Metal sector fell from 11.05 and 7.46 in January 2010 to 7.11 and 5.82 in September 2011 respectively. However, with the Sectors performing well overall this reduction in percentage stockholdings may have further affected the performance of the Fund. The holdings in the Communications sector had not changed much. This along with the severe crisis the Telecommunication Industry is going through may have further reduced the reruns. Though there has been a stability in the Technology sector, FMCG sector has seen a sharp increase and as these sectors are performing well overall, but the increase in percentage stock holdings in them have not been that high to counter the adverse effect of the other sector holding. Thus, it did not help the returns much (Graph 5, Table 3).

c) The major changes in the company holdings happened in Bharti Airtel (2.25 to 3.2), Bank of Baroda (0 to 2.47), BPCL (0-2.49), Oil India (0 to 1.57), and Reliance Industries (0 to 2.49) which is obviously reflected in the returns generated (Graph 6, Table 4).

\subsection{UTI OPPORTUNITIES:}

In January 2010 it garnered very high return (5.62, though not as high as the private funds studied here) which had dropped a badly in March 2010 (-0.75) but again picked up very well in September 2010 (15.32). However the downfall began in December 2010 onwards when the return was 1.84 and continued plummeting further in March 2011 (-5.05), June 2011 (0.29) and September 2011 (-4.6). However, the negative return in September 2011 is not as low as compared to the private funds studied here (Graph 7). This negative turn can be explained as:

a) Same as 1 .

b) The major sector holdings were Financial, Energy, Construction, FMCG, Metals and Technology. The stockholdings in Energy Sector was stable at around 13\%, which is quite high. The energy (especially crude oil) crisis deepened from early 2011 with oil prices skyrocketing. This may have affected the returns generated towards the later quarters of 2011. The stockholdings in the Metals and Technology sector fell from 11.3 and 9.48 in January 2010 to 1.35 and 6.54 in September 2011 respectively. However, with the Sectors performing well overall this reduction in percentage stockholdings may have further affected the performance of the Fund. The holdings in the Communications sector had also increased considerably from 0 to 2.56 . This along with the severe crisis the Telecommunication Industry is going through may have further reduced the returns. Though there has been a sharp rise in the FMCG, Construction and Cons Durable sector and in spite of these sectors performing well overall, the increase in percentage stock holdings have not been high enough to counter the adverse effect of the other sector holdings. Thus, it did not help the returns much (Graph 8, Table 5).

c) The major changes in the company holdings happened in Bharti Airtel (0 to 1.88), Cairn India (0 to 3.87), ITC (2.5 to 6.96) and Titan Industries (0 to 4.54), which is reflected in the returns generated (Graph 9, Table 6).

\section{Conclusion}

Comparing the returns of the Private and Public Sector Funds the following conclusions were drawn: a) The economy performed well in the $1^{\text {st }}$ quarter of 2010 then dipping a little and picking up momentum in September quarter of 2010. This is reflected in the returns of all the chosen funds. The recovering economy again faced a down ward turn from December 2010 due to international debt crisis, political, social and economic problems in India, which is still continuing. This has also clearly affected the Financial markets and thereby the Mutual Fund Industry as a whole. Thus, the better performing funds fluctuate along with the fluctuating economy. Thus, there is a correlation between fund performance and financial market fluctuations brought on by the Global Economic Crisis.

b) The returns are also linked with the sector performance. All the funds had majorly invested in the Energy and Communications sector, which met with a crisis thereby reducing returns. It was also seen that few funds had reduced their percentage holdings in the better performing sectors like Financial, Technology, Services and FMCG, thereby not being able to benefit from the sector returns. Thus, there is a correlation between Sector Holdings, performance of those sectors in the economy and returns generated by the Mutual Fund Schemes.

c) The returns generated by the Public Sector Funds are not as high compared to the Private Sector Funds and the negative returns are also more controlled in the Public Sector Funds as compared to the Private Sector Funds. This is partly due to the difference in sector holdings and also due to the conservative nature of investment followed by the public sector funds. 
Thus from the above study one can interpret that Economic fluctuations affect the Indian Financial market including the Mutual Fund Industry and that Sector Holdings and thereby Company Holdings of Mutual Funds have an influence on their Return and Performance. This is because Sector Performances are linked with the market trends and fluctuations, which in turn affect the Mutual Funds Performance.

The major limitation of this study is that I have chosen only 3 schemes and thus the study can be elaborated on more schemes and also over a longer period of time. This would help in drawing a trend analysis based on Sector Holdings. An extension of this study can delve into the risk-return analysis of Mutual Fund Schemes and Sector Holdings over a substantial time period.

The relevance of this study lies in the analysis of sector holdings so that retail investors in general can apply the findings when they select a portfolio or fund. Besides this, the investors would also understand the reasons behind the fluctuating returns of their Mutual Fund Scheme in context with the Sector Holdings and Market Fluctuations.

\section{Graphs and Tables}

Graph 1: Return Generated by HDFC Equity:

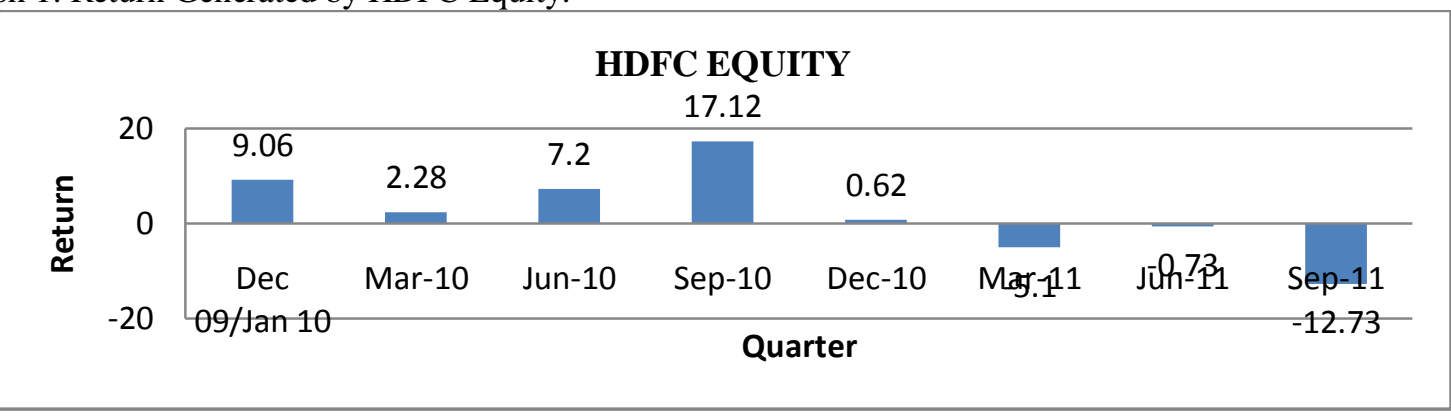

Graph 2: Sector Holdings of HDFC Equity:

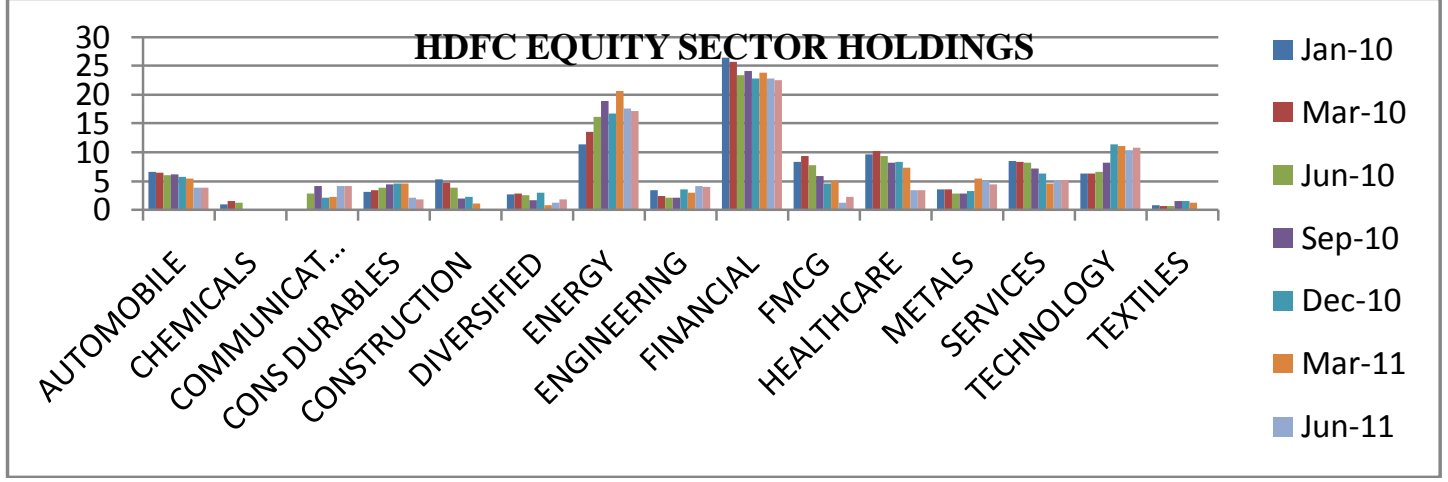

Table 1: Sector Holdings of HDFC Equity:

\begin{tabular}{|l|r|r|r|r|r|r|r|r|r|}
\multicolumn{1}{c|}{ SECTOR } & \multicolumn{10}{|c|}{ HDFC EQUITY (27) } \\
\hline Column1 & Jan-10 & Mar-10 & Jun-10 & Sep-10 & Dec-10 & Mar-11 & Jun-11 & Sep-11 \\
\hline AUTOMOBILE & 6.49 & 6.32 & 6 & 6.14 & 5.59 & 5.4 & 3.84 & 3.83 \\
\hline CHEMICALS & 0.86 & 1.44 & 1.12 & 0 & 0 & 0.06 & 0 & 0 \\
\hline COMMUNICATION & 0 & 0 & 2.79 & 4.11 & 1.99 & 2.3 & 4.12 & 4.1 \\
\hline CONS DURABLES & 3 & 3.38 & 3.77 & 4.4 & 4.45 & 4.57 & 2 & 1.74 \\
\hline CONSTRUCTION & 5.27 & 4.7 & 3.82 & 1.95 & 2.15 & 1.14 & 0 & 0 \\
\hline DIVERSIFIED & 2.56 & 2.71 & 2.5 & 1.54 & 2.9 & 0.75 & 1.2 & 1.76 \\
\hline ENERGY & 11.26 & 13.47 & 16.06 & 18.82 & 16.69 & 20.64 & 17.6 & 17.1 \\
\hline ENGINEERING & 3.32 & 2.32 & 1.97 & 2.03 & 3.43 & 3.01 & 4.08 & 3.98 \\
\hline FINANCIAL & 26.33 & 25.69 & 23.31 & 24.08 & 22.7 & 23.83 & 22.81 & 22.48 \\
\hline FMCG & 8.28 & 9.24 & 7.65 & 5.75 & 4.56 & 4.96 & 1.21 & 2.14 \\
\hline HEALTHCARE & 9.56 & 10.12 & 9.32 & 8.07 & 8.3 & 7.26 & 3.38 & 3.35 \\
\hline
\end{tabular}


Sector holdings in mutual fund performance: an analysis

\begin{tabular}{|l|r|r|r|r|r|r|r|r|r|}
\hline METALS & 3.43 & 3.47 & 2.81 & 2.74 & 3.21 & 5.48 & 4.95 & 4.37 \\
\hline SERVICES & 8.4 & 8.27 & 8.08 & 7.14 & 6.18 & 4.61 & 5.07 & 5.06 \\
\hline TECHNOLOGY & 6.3 & 6.2 & 6.52 & 8.15 & 11.31 & 11.09 & 10.31 & 10.73 \\
\hline TEXTILES & 0.7 & 0.64 & 0.56 & 1.5 & 1.48 & 1.21 & 0 & 0 \\
\hline
\end{tabular}

Graph 3: Company Holdings of HDFC Equity:

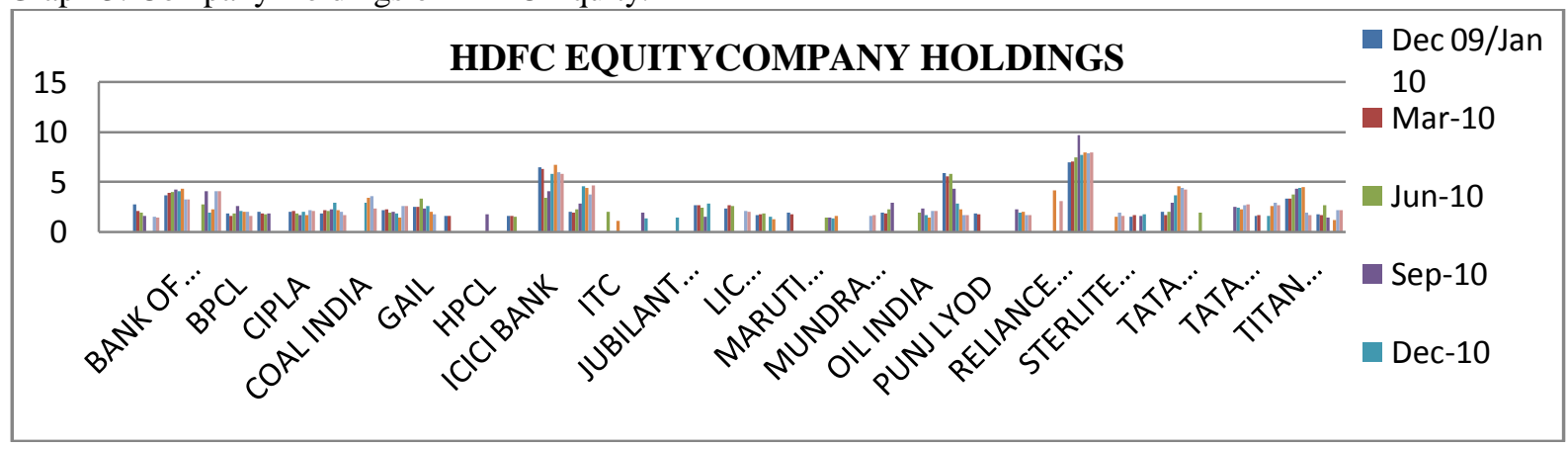

Table 2: Company Holdings of HDFC Equity:

\begin{tabular}{|c|c|c|c|c|c|c|c|c|}
\hline \multirow{2}{*}{$\begin{array}{l}\text { COMPANY } \\
\text { COMPANY }\end{array}$} & \multicolumn{8}{|c|}{ HDFC EQUITY (27) } \\
\hline & Jan 10 & Mar-10 & Jun-10 & Sep-10 & Dec-10 & Mar-11 & Jun-11 & Sep-11 \\
\hline AXIS BANK & 2.8 & 2.16 & 1.94 & 1.65 & 0 & 0 & 1.6 & 1.47 \\
\hline BANK OF BARODA & 3.73 & 3.92 & 4.02 & 4.29 & 4.16 & 4.34 & 3.3 & 3.31 \\
\hline BHARTI AIRTEL & 0 & 0 & 2.79 & 4.11 & 1.99 & 2.3 & 4.12 & 4.1 \\
\hline BPCL & 1.9 & 1.68 & 1.92 & 2.67 & 2.16 & 2.04 & 2.05 & 1.67 \\
\hline CIPLA & 2.08 & 2.14 & 1.86 & 1.69 & 2.04 & 1.73 & 2.23 & 2.17 \\
\hline $\mathrm{CMC}$ & 1.91 & 2.19 & 2.12 & 2.33 & 2.96 & 2.23 & 2.02 & 1.71 \\
\hline COAL INDIA & 0 & 0 & 0 & 0 & 2.93 & 3.43 & 3.59 & 2.4 \\
\hline CROMPTON GREAVES & 2.2 & 2.32 & 1.97 & 2.03 & 1.89 & 1.52 & 2.65 & 2.6 \\
\hline GAIL & 2.55 & 2.52 & 3.35 & 2.4 & 2.63 & 2.04 & 1.79 & 0 \\
\hline ICICI BANK & 6.5 & 6.34 & 3.43 & 4.09 & 5.89 & 6.76 & 6.05 & 5.88 \\
\hline INFOSYS & & & & & & & & \\
\hline OLOGIES & 2.08 & 2.01 & 2.3 & 2.85 & 4.64 & 4.47 & 3.82 & 4.71 \\
\hline ITC & 0 & 0 & 2.03 & 0 & 0 & 1.18 & 0 & 0 \\
\hline LIC HOUSING FIN & 2.4 & 2.68 & 2.66 & 0 & 0 & 0 & 2.15 & 2.08 \\
\hline LUPIN & 1.73 & 1.8 & 1.9 & 0 & 1.6 & 1.34 & 0 & 0 \\
\hline MOTHE & & & & & & & & \\
\hline SYS & 0 & 0 & 1.48 & 1.52 & 1.4 & 1.61 & 0 & 0 \\
\hline MUND & 0 & 0 & 0 & 0 & 0 & 0 & 1.61 & 1.69 \\
\hline OIL INDIA & 0 & 0 & 1.96 & 2.4 & 1.76 & 1.45 & 2.12 & 2.13 \\
\hline ONGC & 5.95 & 5.62 & 5.85 & 4.33 & 2.89 & 2.32 & 1.77 & 1.74 \\
\hline $\begin{array}{l}\text { PUNJAB NATIONAL } \\
\text { BANK }\end{array}$ & 0 & 0 & 0 & 2.3 & 2 & 2.03 & 1.76 & 1.75 \\
\hline $\begin{array}{l}\text { RELIANCE } \\
\text { INDUSTRIES }\end{array}$ & 0 & 0 & 0 & 0 & 0 & 4.24 & 0 & 3.16 \\
\hline $\begin{array}{l}\text { STATE BANK OF } \\
\text { INDIA }\end{array}$ & 7.01 & 7.09 & 7.5 & 9.69 & 7.75 & 7.99 & 7.95 & 7.99 \\
\hline STERLI & & & & & & & & \\
\hline INDU: & 0 & 0 & 0 & 0 & 0 & 1.57 & 1.96 & 1.68 \\
\hline TCS & 2.03 & 1.77 & 2.1 & 2.97 & 3.71 & 4.59 & 4.47 & 4.31 \\
\hline TATA MOTORS DVR & 0 & 0 & 0 & 2.59 & 2.5 & 2.31 & 2.72 & 2.8 \\
\hline TATA STEEL & 1.67 & 1.77 & 0 & 0 & 1.67 & 2.6 & 2.99 & 2.69 \\
\hline TITAN INDUSTRIES & 3.34 & 3.38 & 3.77 & 4.4 & 4.45 & 4.57 & 2 & 1.74 \\
\hline ZEE ENTERTAINMENT & & & & & & & & \\
\hline ENT & 1.82 & 1.72 & 2.72 & 1.5 & 0 & 1.27 & 2.24 & 2.21 \\
\hline
\end{tabular}


Graph 4: Return Generated by Tata Equity PE:

\section{TATA EQUITY PE}

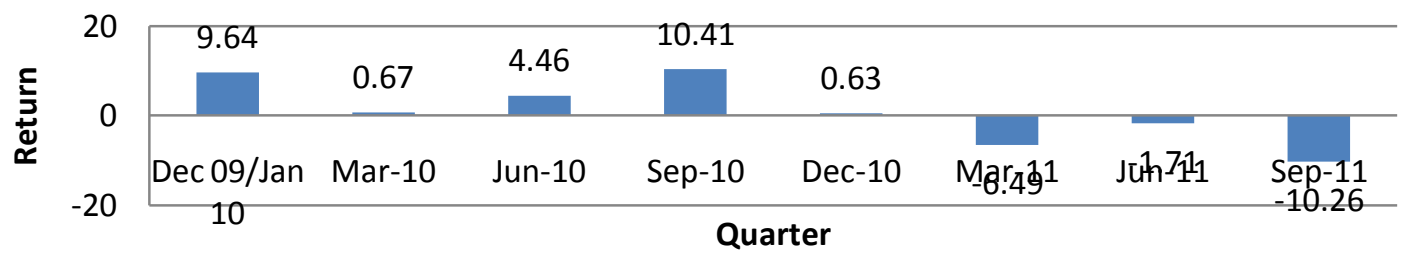

Graph 5: Sector Holdings of Tata Equity PE:

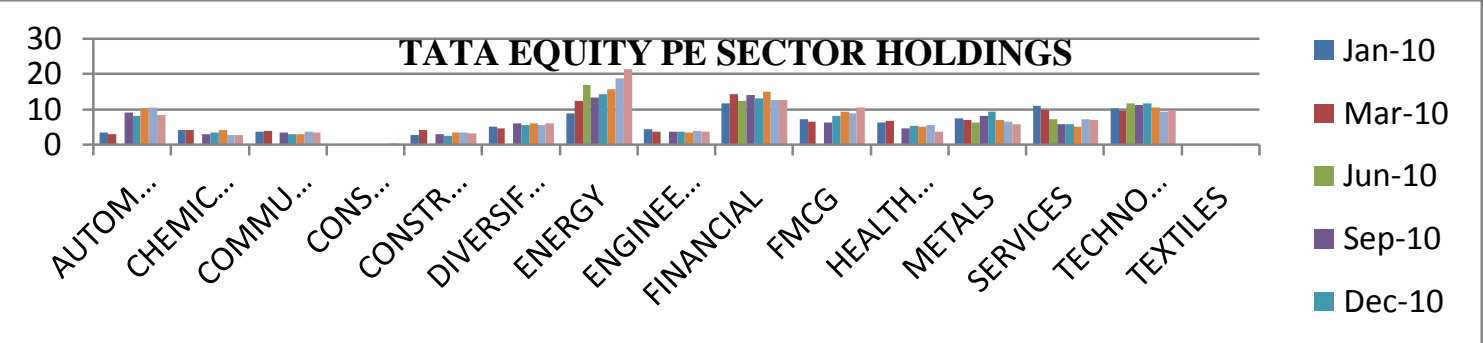

Table 3: Sector Holdings of Tata Equity PE:

\begin{tabular}{|l|r|r|r|r|r|r|r|r|}
\hline \begin{tabular}{|l|r|} 
SECTOR \\
Column1
\end{tabular} & Jan-10 & Mar-10 & Jun-10 & Sep-10 & Dec-10 & Mar-11 & Jun-11 & Sep-11 \\
\hline AUTOMOBILE & 3.53 & 3.13 & & 9.1 & 8.13 & 10.35 & 10.64 & 8.37 \\
\hline CHEMICALS & 4.33 & 4.28 & & 3.14 & 3.52 & 4.01 & 2.82 & 2.74 \\
\hline COMMUNICATION & 3.82 & 3.95 & & 3.49 & 3.06 & 3 & 3.75 & 3.51 \\
\hline CONS DURABLES & 0 & 0 & & -0 & $\mathrm{~h}$ & 0 & 0 & 0.46 \\
\hline CONSTRUCTION & 2.7 & 4.11 & & 2.98 & 2.47 & 3.47 & 3.5 & 3.32 \\
\hline DIVERSIFIED & 5.16 & 4.73 & & 6.14 & 5.51 & 5.97 & 5.74 & 6.09 \\
\hline ENERGY & 8.82 & 12.43 & 16.93 & 13.27 & 14.31 & 15.73 & 18.65 & 21.38 \\
\hline ENGINEERING & 4.55 & 3.71 & & 3.73 & 3.73 & 3.47 & 3.99 & 3.86 \\
\hline FINANCIAL & 11.74 & 14.36 & 12.37 & 14.1 & 13.12 & 14.97 & 12.71 & 12.65 \\
\hline FMCG & 7.38 & 6.51 & & 6.41 & 8.3 & 9.27 & 8.81 & 10.53 \\
\hline HEALTHCARE & 6.24 & 6.87 & & 4.65 & 5.29 & 5.08 & 5.67 & 3.72 \\
\hline METALS & 7.46 & 7.07 & 6.38 & 8.22 & 9.39 & 6.91 & 6.45 & 5.82 \\
\hline SERVICES & 11.05 & 9.95 & 7.3 & 5.87 & 5.75 & 5.16 & 7.3 & 7.11 \\
\hline TECHNOLOGY & 10.38 & 9.59 & 11.73 & 11.16 & 11.71 & 10.43 & 9.49 & 9.96 \\
\hline TEXTILES & 0 & 0 & 0 & 0 & 0 & 0.12 & 0 & 0 \\
\hline
\end{tabular}

Graph 6: Company Holdings of Tata Equity PE:

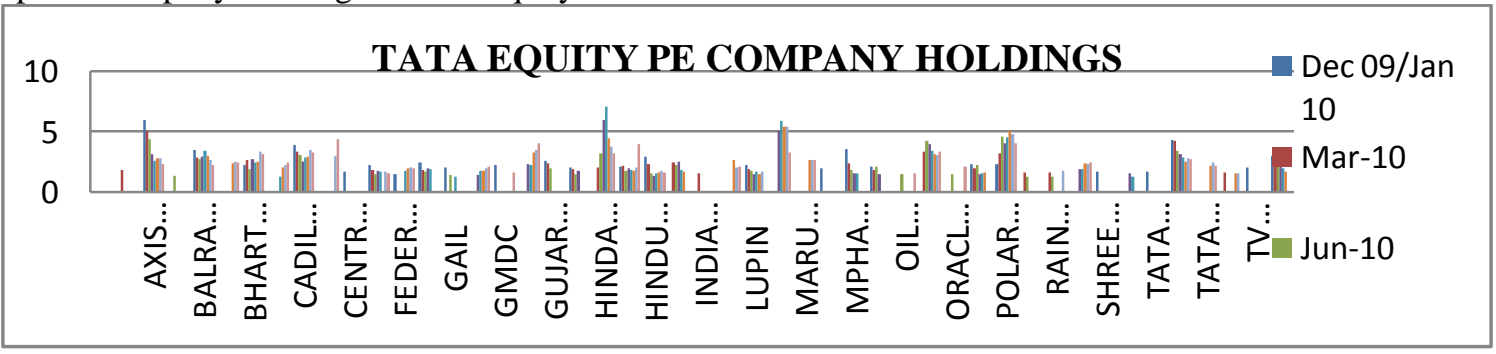

Table 4: Company Holdings of Tata Equity PE:

6.03

3.53

5.1
2.92

\begin{tabular}{|r|r|r|r|r|r|}
\hline Jun-10 & Sep-10 & Dec-10 & Mar-11 & Jun-11 & Sep-11 \\
\hline 4.38 & 3.2 & 2.65 & 2.83 & 2.8 & 2.36 \\
\hline 2.77 & 2.97 & 3.46 & 3.02 & 2.66 & 2.27 \\
\hline
\end{tabular}


Sector holdings in mutual fund performance: an analysis

\begin{tabular}{|l|r|r|r|r|r|r|r|r|}
\hline BANK OF BARODA & 0 & 0 & 0 & 0 & 0 & 2.4 & 2.58 & 2.47 \\
\hline BHARTI AIRTEL & 2.25 & 2.72 & 1.94 & 2.73 & 2.51 & 2.57 & 3.37 & 3.2 \\
\hline BPCL & 0 & 0 & 0 & 0 & 1.29 & 2.06 & 2.3 & 2.49 \\
\hline CADILA HEALTHCARE & 3.94 & 3.39 & 3.07 & 2.58 & 2.88 & 3 & 3.5 & 3.28 \\
\hline CAIRN INDIA & 0 & 0 & 0 & 0 & 0 & 0 & 3.02 & 4.4 \\
\hline FXIDE INDS & 2.3 & 1.89 & 1.49 & 1.82 & 1.75 & 0 & 1.74 & 1.59 \\
\hline GLAXRAL BANK & 1.5 & 0 & 0 & 0 & 1.82 & 1.97 & 2.08 & 1.98 \\
\hline HEALTHCARE & & & & & & & & \\
\hline GMDC & 0 & 0 & 0 & 1.47 & 1.82 & 1.81 & 2.03 & 2.15 \\
\hline GRASIM INDUSTRIES & 2.28 & 0 & 0 & 0 & 0 & 0 & 0 & 1.66 \\
\hline HINDALCO INDS & 0 & 0 & 0 & 2.32 & 2.3 & 3.31 & 3.49 & 4.09 \\
\hline HINDUSTAN UNILEVER & 0 & 2.06 & 3.21 & 6.03 & 7.09 & 4.49 & 3.77 & 3.23 \\
\hline HINDUSTAN ZINC & 2.15 & 2.24 & 1.81 & 1.97 & 1.88 & 1.76 & 2.09 & 3.98 \\
\hline HPCL & 2.94 & 2.36 & 1.56 & 1.36 & 1.61 & 1.66 & 1.79 & 1.65 \\
\hline ITC & 0 & 2.5 & 2.31 & 2.55 & 1.85 & 1.73 & 0 & 0 \\
\hline LUPIN & 0 & 0 & 0 & 0 & 0 & 2.68 & 2.04 & 2.13 \\
\hline MAHINDRA \& MAHINDRA & 2.3 & 1.95 & 1.82 & 1.49 & 1.73 & 1.54 & 1.75 & 0 \\
\hline MARUTI SUZUKI INDIA & 0 & 0 & 0 & 5.12 & 5.91 & 5.45 & 5.48 & 3.32 \\
\hline OIL INDIA & 0 & 0 & 0 & 0 & 0 & 2.72 & 2.71 & 2.66 \\
\hline ONGC & 0 & 0 & 1.49 & 0 & 0 & 0 & 0 & 1.57 \\
\hline ORACLE FIN SER & 0 & 3.35 & 4.26 & 4 & 3.47 & 3.2 & 3.09 & 3.35 \\
\hline SOFTWARE & & & & & & & & \\
\hline PATNI COMPUTER & 0 & 0 & 1.54 & 0 & 0 & 0 & 0 & 2.14 \\
\hline SYSTEMS & 2.36 & 2.01 & 2.31 & 1.51 & 1.62 & 1.67 & 0 & 0 \\
\hline POLARIS SOFTWARE LAB & 2.36 & 3.23 & 4.6 & 4.09 & 4.57 & 5.08 & 4.85 & 4.07 \\
\hline RAIN COMMODITIES & 0 & 1.66 & 1.34 & 0 & 0 & 0 & 1.78 & 0 \\
\hline RELIANCE INDUSTRIES & 0 & 0 & 0 & 1.92 & 1.94 & 2.4 & 2.32 & 2.49 \\
\hline TATA CHEMICALS & 4.33 & 4.28 & 3.44 & 3.14 & 2.91 & 2.57 & 2.82 & 2.74 \\
\hline TATA MOTORS & 0 & 0 & 0 & 0 & 0 & 2.18 & 2.45 & 2.22 \\
\hline TATA POWER & 0 & 1.65 & 0 & 0 & 0 & 1.61 & 1.62 & 0 \\
\hline VOLTAS & 3.01 & 2.9 & 2.41 & 2.33 & 1.99 & 1.7 & 0 & 0 \\
\hline
\end{tabular}

Graph 7: Return Generated by UTI Opportunities:

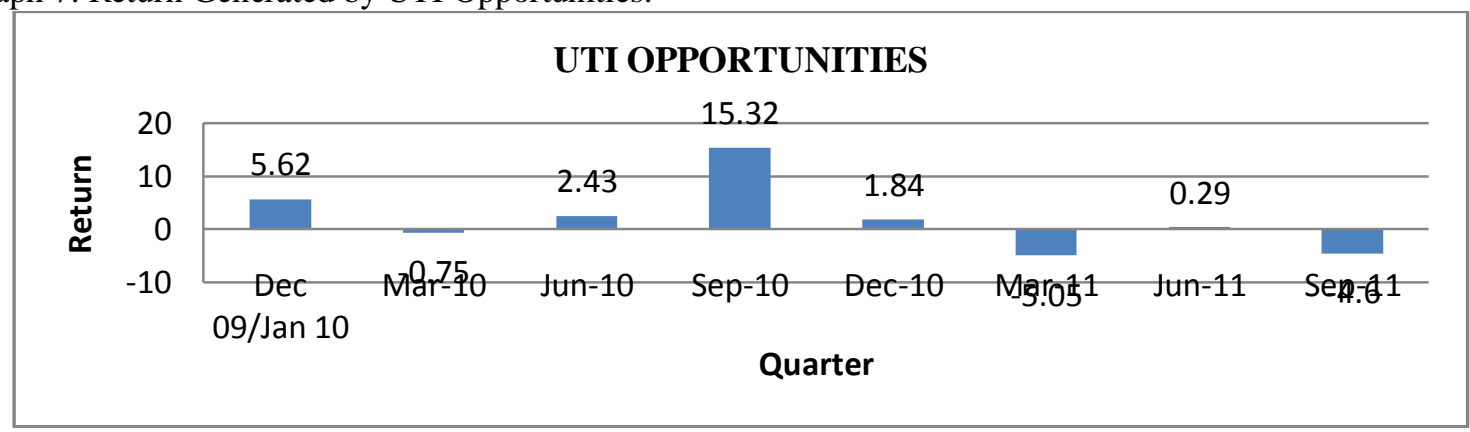

Graph 8: Sector Holdings of UTI Opportunities:

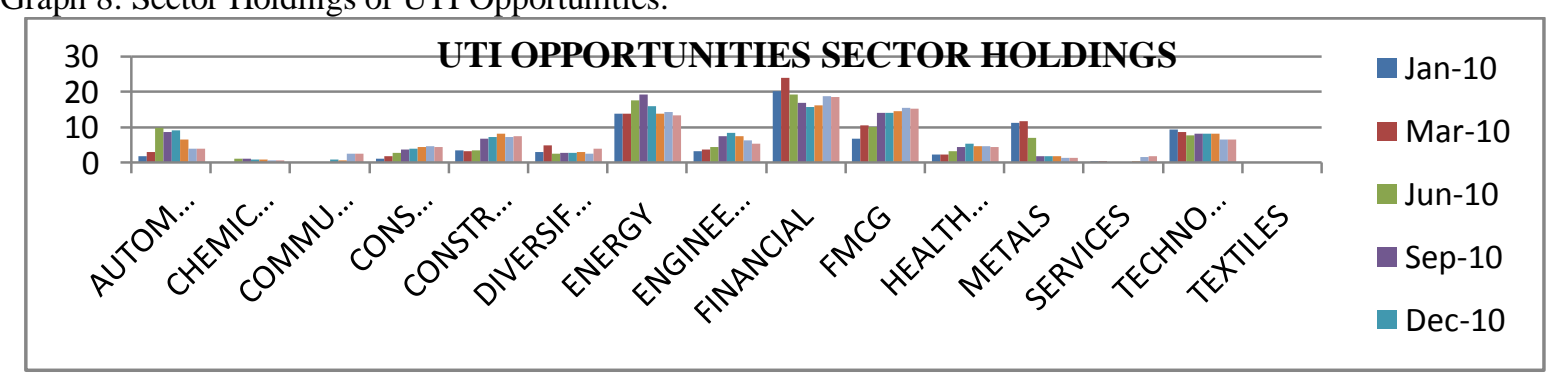


Table 5: Sector Holdings of UTI Opportunities:

\begin{tabular}{|c|c|c|c|c|c|c|c|c|}
\hline \multirow{2}{*}{$\begin{array}{l}\text { SECTOR } \\
\text { Column1 }\end{array}$} & \multicolumn{8}{|c|}{ UTI OPPORTUNITIES (47) } \\
\hline & Jan-10 & Mar-10 & Jun-10 & Sep-10 & Dec-10 & Mar-11 & Jun-11 & Sep-11 \\
\hline AUTOMOBILE & 1.85 & 3.06 & 9.86 & 8.64 & 9.11 & 6.52 & 4.1 & 3.87 \\
\hline CHEMICALS & 0 & 0 & 1.13 & 1.13 & 0.97 & 0.85 & 0.78 & 0.67 \\
\hline COMMUNICATION & 0 & 0 & 0 & 0 & 1.05 & 0.82 & 2.68 & 2.56 \\
\hline CONS DURABLES & 1.27 & 1.98 & 2.79 & 3.84 & 4.1 & 4.46 & 4.58 & 4.54 \\
\hline CONSTRUCTION & 3.5 & 3.24 & 3.45 & 6.83 & 7.31 & 8.32 & 7.22 & 7.48 \\
\hline DIVERSIFIED & 3.01 & 4.83 & 2.54 & 2.82 & 2.89 & 3.11 & 2.63 & 4.04 \\
\hline ENERGY & 13.89 & 13.72 & 17.67 & 19.26 & 15.89 & 13.78 & 14.3 & 13.37 \\
\hline ENGINEERING & 3.19 & 3.68 & 4.38 & 7.61 & 8.34 & 7.51 & 6.36 & 5.31 \\
\hline FINANCIAL & 20.19 & 24.02 & 19.18 & 16.95 & 15.81 & 16.13 & 18.8 & 18.42 \\
\hline FMCG & 6.7 & 10.62 & 10.11 & 14.06 & 14.15 & 14.47 & 15.4 & 15.13 \\
\hline HEALTHCARE & 2.42 & 2.32 & 3.36 & 4.53 & 5.3 & 4.6 & 4.62 & 4.34 \\
\hline METALS & 11.3 & 11.63 & 7.09 & 1.8 & 1.76 & 1.76 & 1.42 & 1.35 \\
\hline SERVICES & 0.47 & 0.43 & 0 & 0 & 0 & 0.38 & 1.72 & 1.76 \\
\hline TECHNOLOGY & 9.48 & 8.7 & 7.83 & 8.29 & 8.14 & 8.19 & 6.49 & 6.54 \\
\hline TEXTILES & 0 & 0 & 0 & 0 & 0 & 0 & 0 & 0 \\
\hline
\end{tabular}

Graph 9: Company Holdings of UTI Opportunities:

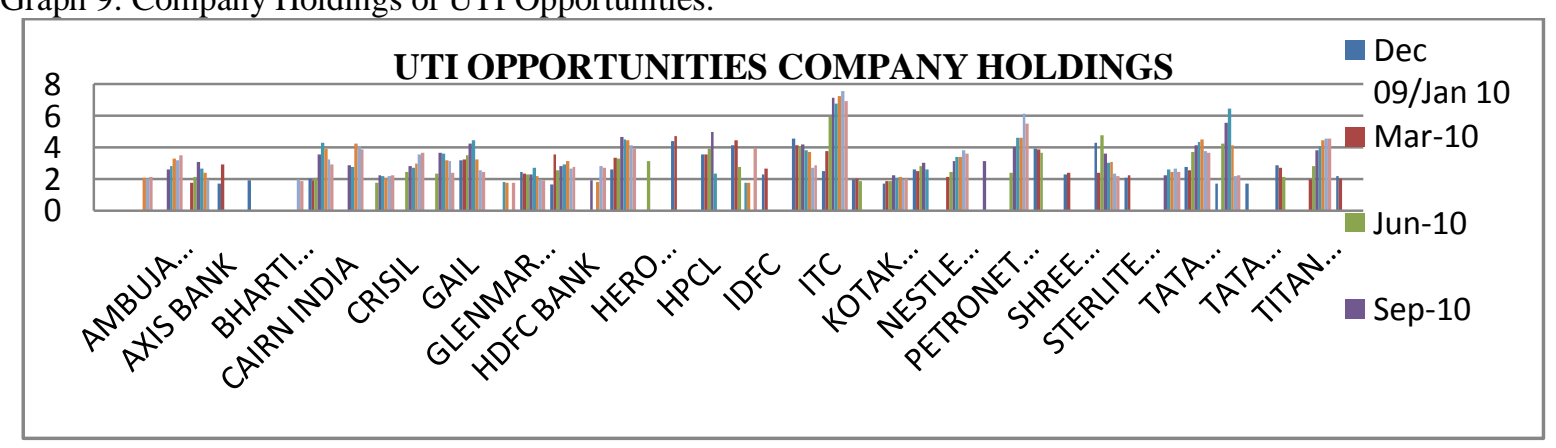

Table 6: Company Holdings of UTI Opportunities:

\begin{tabular}{|c|c|c|c|c|c|c|c|c|}
\hline COMPANY & \multicolumn{8}{|c|}{ UTI OPPORTUNITIES (47) } \\
\hline COMPANY & Jan 10 & Mar-10 & Jun-10 & Sep-10 & Dec-10 & Mar-11 & Jun-11 & Sep-11 \\
\hline $\mathrm{ACC}$ & 0 & 0 & 0 & 0 & 0 & 2.04 & 1.99 & 2.13 \\
\hline AMBUJA CEMENTS & 0 & 0 & 0 & 2.57 & 2.83 & 3.3 & 3.2 & 3.5 \\
\hline ASHOK LEYLAND & 0 & 1.77 & 2.11 & 3.07 & 2.65 & 2.41 & 1.94 & 0 \\
\hline BHARTI AIRTEL & 0 & 0 & 0 & 0 & 0 & 0 & 1.97 & 1.88 \\
\hline BHEL & 2.03 & 1.91 & 2.05 & 3.54 & 4.3 & 3.94 & 3.21 & 2.91 \\
\hline CAIRN INDIA & 0 & 0 & 0 & 2.86 & 2.76 & 4.23 & 4.06 & 3.87 \\
\hline $\begin{array}{l}\text { COLGATE } \\
\text { PALMOLIVE (I) }\end{array}$ & 0 & 0 & 1.77 & 2.21 & 2.15 & 2.06 & 2.18 & 2.2 \\
\hline CRISIL & 0 & 0 & 2.45 & 2.8 & 2.69 & 2.95 & 3.54 & 3.66 \\
\hline EXIDE INDS & 0 & 0 & 2.33 & 3.63 & 3.61 & 3.17 & 3.15 & 2.4 \\
\hline GAIL & 3.2 & 3.25 & 3.48 & 4.24 & 4.43 & 3.23 & 2.52 & 2.46 \\
\hline $\begin{array}{l}\text { GLAXO CONSUMER } \\
\text { HEALTHCARE }\end{array}$ & 0 & 0 & 0 & 0 & 1.8 & 1.77 & 0 & 1.74 \\
\hline $\begin{array}{l}\text { GLENMARK } \\
\text { PHARMA }\end{array}$ & 2.42 & 2.32 & 2.27 & 2.28 & 2.68 & 2.15 & 1.96 & 1.9 \\
\hline GRASIM INDUSTRIES & 1.64 & 3.54 & 2.54 & 2.82 & 2.89 & 3.11 & 2.63 & 2.75 \\
\hline HDFC BANK & 0 & 0 & 0 & 1.9 & 0 & 1.78 & 2.81 & 2.72 \\
\hline HDFC & 2.58 & 3.32 & 3.31 & 4.65 & 4.5 & 4.43 & 4.14 & 3.91 \\
\hline ICICI BANK & 4.15 & 4.45 & 2.73 & 0 & 1.77 & 1.76 & 0 & 3.95 \\
\hline INFOSYS & 4.54 & 4.13 & 4.08 & 4.16 & 3.82 & 3.69 & 2.71 & 2.86 \\
\hline
\end{tabular}


Sector holdings in mutual fund performance: an analysis

\begin{tabular}{|l|r|r|r|r|r|r|r|r|}
\hline TECHNOLOGIES & & & & & & & \\
\hline ITC & 2.5 & 3.78 & 5.93 & 7.13 & 6.79 & 7.25 & 7.58 & 6.96 \\
\hline KOTAK MAHINDRA & & & & & & & & \\
\hline BANK & 1.69 & 1.88 & 1.85 & 2.24 & 2.07 & 2.14 & 1.97 & 2 \\
\hline NESTLE INDIA & 0 & 2.11 & 2.42 & 3.11 & 3.41 & 3.39 & 3.83 & 3.62 \\
\hline PETRONET LNG & 0 & 0 & 2.41 & 4.03 & 4.63 & 4.62 & 6.13 & 5.5 \\
\hline STATE BANK OF & 4.29 & 2.36 & 4.75 & 3.6 & 3.04 & 3.06 & 2.31 & 2.19 \\
\hline INDIA & & & & & & & & \\
\hline $\begin{array}{l}\text { SUN } \\
\text { PHARMACEUTICAL }\end{array}$ & & & & & & & & \\
INDS & & & & & & & & \\
\hline TATA & & & & & & & \\
CONSULTANCY & 2.76 & 2.52 & 3.73 & 4.12 & 4.32 & 4.49 & 3.76 & 3.66 \\
\hline SERVICES & 1.69 & & 4.22 & 5.57 & 6.46 & 4.12 & 2.16 & 2.22 \\
\hline TATA MOTORS & 0 & 1.98 & 2.79 & 3.84 & 4.1 & 4.46 & 4.58 & 4.54 \\
\hline TITAN INDUSTRIES & & & & & & &
\end{tabular}

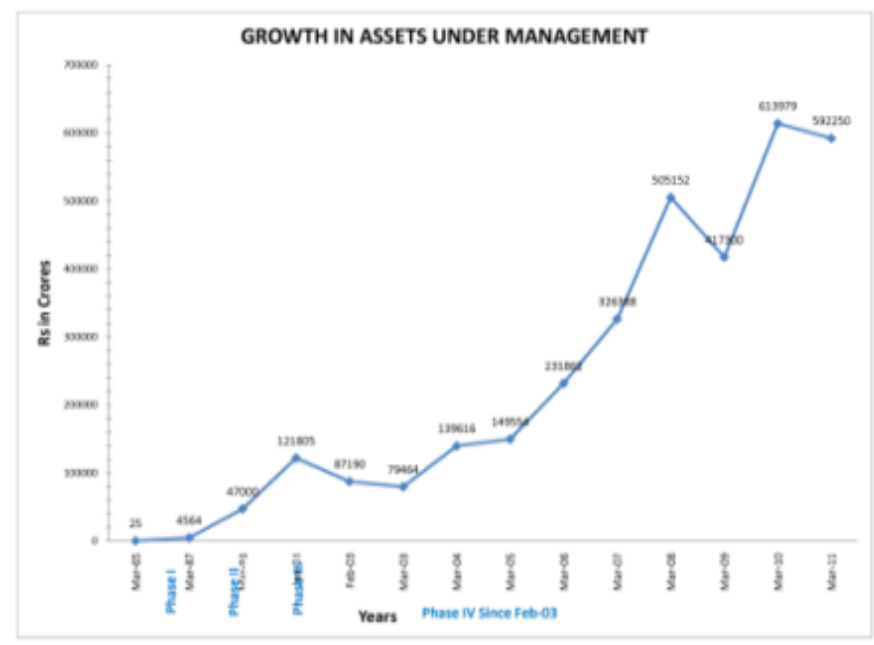

Source: www.amfi.com

Figure 1: Growth of Mutual Funds:

\section{Structure}

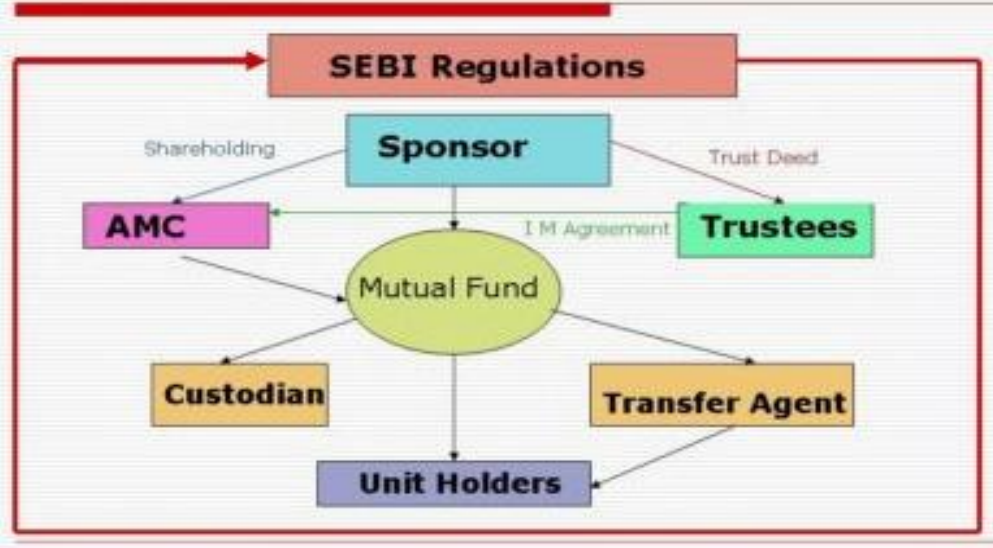

Source: www.personalfn.com

Fig 2: Structure of Mutual Fund Industry. 


\section{REFERENCE}

[1]. Singh D., Mutual Funds in India (Rajat Publications, New Delhi, 2003).

[2]. Sadhak H., Mutual Funds in India-Marketing Strategies and Investment Practices( Response Books, New Delhi,2003).

[3]. Sadhak H., Mutual Funds in India-Marketing Strategies and Investment Practices( Response Books, New Delhi,2003).

[4]. Singh H., Mutual Funds and the Indian Capital Market-Performance and Profitability( Kanishka Publisher, Distributors, New Delhi, 2001).

[5]. Singh H., Mutual Funds and the Indian Capital Market-Performance and Profitability( Kanishka Publisher, Distributors, New Delhi, 2001).

[6]. Dave S. Mutual Funds in India: Challenges, Opportunities and Strategic Perspectives (UTI Institute of Capital Markets, Mumbai, 1996).

[7]. Sondhi., Financial Performance of Equity Mutual Funds in India (ICFAI University Press, Hyderabad,2004).

[8]. Bansal L., Mutual Funds Management and Working (Deep and Deep Publications, New Delhi, 1997).

[9]. Baid R., IIBF: Mutual Fund Product and Services (Taxman, New Delhi,2007).

[10]. Sen B., Mutual Funds in India: Challenges, opportunities and Strategic Perspectives (UTI Institute of Capital Markets, Mumbai,1996).

[11]. Sahadevan and Thiripalraju.,Mutual Funds Data Interpretation and Analysis (PHI, New Delhi, 1997).

[12]. Sharpe W. F., Mutual Fund Performance, Journal of Business, 39, 1966, 119-138.

[13]. Treynor and Mazuy, Can Mutual Funds Outguess The Markets, Harvard Business Review, 44, 1966, $131-136$.

[14]. Guhadeb and Banerjee, Value at Risk of Mutual Funds, The International Research Journal of Finance and Economics, 23, 2009, 217-230.

[15]. Roy B. and Deb S., Conditional performance of Indian Mutual Funds, ICFAI University Press, 2003, Working paper, http://papers.ssrn.com/sol3/papers.cfm?abstract_id=593723.

[16]. Ferson and Schadt, Measuring Fund Strategy and Performance in changing Economic Conditions, The Journal of Finance, 51, $1996,425-461$.

[17]. Wohar, Determinants of persistence in relative performance of Mutual Funds, The Journal of Financial Research, 18(4), 1995, 415430 .

\section{Websites:}

www.amfindia.com; www.mutualfundsindia.com; www.personalfn.com; $w$ ww.valueresearchonline.com. 